\title{
ФОРМУВАННЯ РЕЖИМУ СОЛОНОСТІ ВОД ДНІПРОВСЬКО-БУЗЬКОЇ ГИРЛОВОЇ ОБЛАСТІ ПІД ВПЛИВОМ КЛІМАТИЧНИХ ЗМІН У СУЧАСНИЙ ПЕРІОД
}

\author{
Коржов Є. I., Гончарова О. В.
}

\section{ВСТУП}

Глобальні кліматичні зміни, які відбулися в останні десятиліття на земній кулі, щорічно призводять до значних соціально-економічних збитків. Через збільшення температури повітря i, відповідно, водного середовища у водних екосистемах різних рівнів відбуваються крупномасштабні структурно-функціональні перебудови основних біотичних угруповань. Зміна умов існування гідробіонтів призводить до їх міграції у більш сприятливі умови, що спричиняє переформування видового складу та потоків енергії в екосистемах локального рівня. Найбільш помітним цей процес $є$ у незначних за розміром і неглибоких водних об'єктах суші, оскільки саме вони найбільш чутливі до змін гідрологічного та гідрохімічного режимів регіону, в якому розташовані.

До таких водних об'єктів належить Дніпровсько-Бузька гирлова область. Вона розташована в центральній частині Причорноморської низовини та включає в себе гирлові ділянки Дніпра та Південного Бугу і Дніпровсько-Бузький лиман (рис. 1).

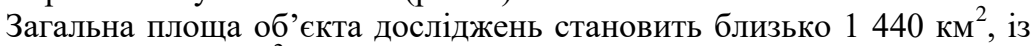
яких близько 500 км $^{2}$ охоплює гирлова ділянка Дніпра, що включає в себе руслову мережу, заплавні водойми та переважно заболочені

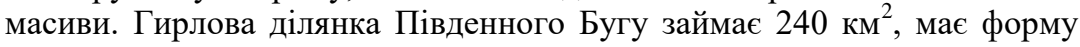
переважно без острівного естуарію зі значно звивистим руслом.

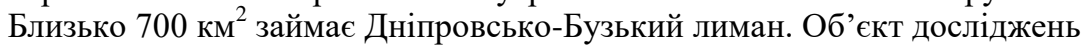
на сході обмежується гирловою ділянкою Дніпра, яка розпочинається від Каховської ГЕС, Кінбурнською протокою на заході та селом Новопетрівське у Бузькому лимані на півночі ${ }^{1,2,3}$.

1 Timchenko V.M., Korzhov Y.I., Guliayeva O.A., Batog S.V. Dynamics of Environmentally Significant Elements of Hydrological Regime of the Lower Dnieper Section. Hydrobiological Journal. Begell House (United States). Vol. 51. Issue 6. 2015. P. 75-83. DOI: 10.1615/HydrobJ.v51.i6.90.

Коржов Є.I., Бородін А.В. Гідрографічна характеристика ДніпровськоБузького лиману в межах НПП «Нижньодніпровського». Наукові читання, присвячені Дню науки. Екологічні дослідження Дніпровсько-Бузького регіону. Херсон, 2018. Вип. 11. С. 56-59.

Коржов Е.И. Современная гидрографическая характеристика низовья Днепра. Наукові читання присвячені Дню науки. Херсон, 2011. Вип. 4. С. 4-17. 


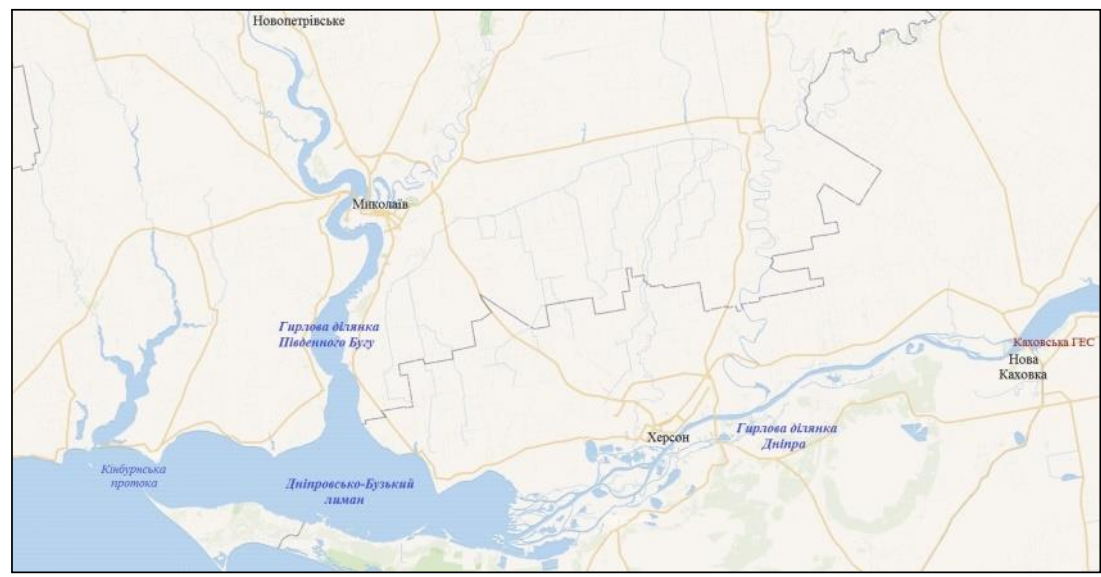

\section{Рис. 1. Схема розташування Дніпровсько-Бузької гирлової області}

Режим солоності області переважно формується під впливом прісноводого річкового стоку та надходження солоних вод із Чорного моря через Кінбурнську протоку. Зважаючи на те, що кліматичні фактори насамперед формують балансові характеристики водного об'єкта, їх зміна може бути вагомим важелем переформування як гідрологічного, так і гідрохімічного режиму водних екосистем.

\section{1. Аналіз прісноводного стоку}

Основний притік прісних вод до Дніпровсько-Бузької гирлової області відбувається за рахунок стоку Дніпра, що формує його на 94\%. Останніми роками простежується тенденція зниження річкового стоку. На нашу думку, така тенденція пов'язана з переходом до маловодної фази водності Дніпра багатовікового циклу, що почалася на початку 40-х pp. минулого століття. Нами був проаналізований ряд спостережень за стоком Дніпра за 195 років - із 1820 по 2015 р. (рис. 2).

Багатоводні та маловоді фази з різною тривалістю тут змінюються послідовно. Лінія тренду виражається рівнянням: $W=-0,1014$ $t+245,12$, та вказує на поступове скорочення стоку Дніпра з роками $(t)$ у гирловій ділянці.

Згідно із працями Г.І. Швеця ${ }^{4}$ за 3816 років (починаючи з 1874 р. до н. е.) на Дніпрі можна помітити дві фази багатовікового циклу: маловодну і багатоводну.

4 Швец Г.И. Многовековая изменчивость стока Днепра. Москва : Гидрометеоиздат, 1979.84 с. 


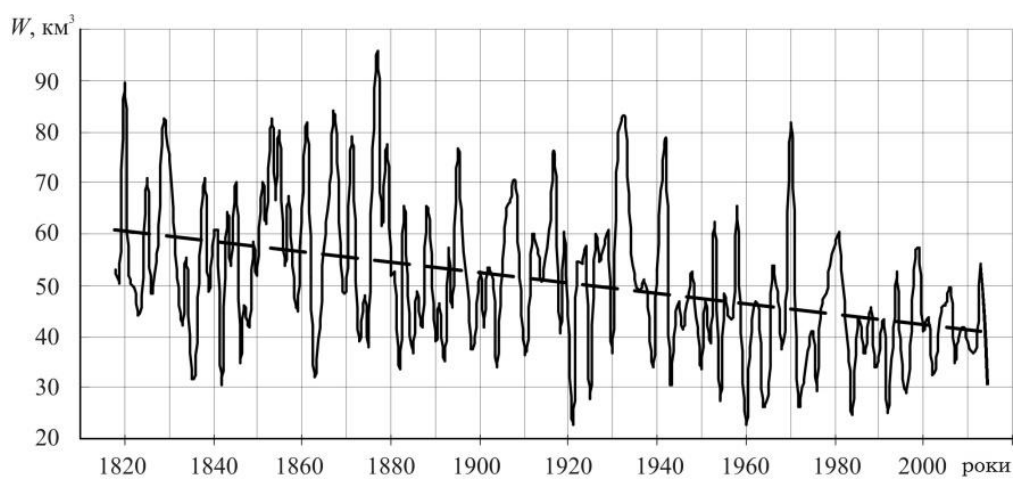

\section{Рис. 2. Багаторічний розподіл стоку Дніпра у його гирловій ділянці ${ }^{5,6}$}

Маловодна фаза тривала 2596 років (з 1874 р. до н. е. по 722 р. н. е.). Характерним $\epsilon$ те, що сумарна тривалість внутрішньовікових маловодних фаз перевершує багатоводні в 2,1 рази. Середнє значення річного стоку за маловодну фазу багатовікового циклу складало 97\% від норми.

Багатоводна фаза багатовікового циклу тривала 1221 рік (з 772 по 1942 pp.). Особливо багатоводними вважаються X-XII ст., на що вказують руські літописи. Впродовж багатовікової багатоводної фази тривалість внутрішньовікових багатоводних фаз перевищувала тривалість маловодних майже на $80 \%$. Середнє значення річного стоку за цю фазу багатовікового циклу склало $102 \%$ від норми.

Результати аналізу річкового стоку Дніпра за багатовіковий період дозволили Г.І. Швецю вважати, що його мінливість характеризується циклічністю без односторонньої тенденції зміни у багатовіковому масштабі.

Побудована нами різницева інтегральна крива модульних коефіцієнтів річкового стоку, отримана при продовженні ряду даних Г.І. Швеця щодо водності Дніпра підтверджує, що після 1942 p. почалася нова маловодна фаза багатовікового циклу (рис. 3$)^{7}$.

Зазначимо, що перехід між фазами багатовікових циклів відбувається без чіткого розмежування між ними. На Дніпрі у

5 Timchenko V.M., Korzhov Y.I., Guliayeva O.A., Batog S.V. Dynamics of Environmentally Significant Elements of Hydrological Regime of the Lower Dnieper Section. Hydrobiological Journal. Begell House (United States). 2015. Vol. 51. Issue 6. P. 75-83. DOI: 10.1615/HydrobJ.v51.i6.90.

${ }^{6}$ Коржов Е.И. Некоторые экологически значимые аспекты водного режима Нижнего Днепра. Наукові читання присвячені Дню науки. Херсон, 2010. Вип. 3. С. 4-9.

Коржов Е.И. Некоторые экологически значимые аспекты водного режима Нижнего Днепра. Наукові читання присвячені Дню науки. Херсон, 2010. Вип. 3. С. 4-9. 
минулому столітті тривалість такого переходу становила близько 60 років - 31880 по 1942 р. (див. рис. 3). Перехід до сучасної маловодної фази багатовікового циклу збігся із початком створення каскаду водосховищ на Дніпрі.

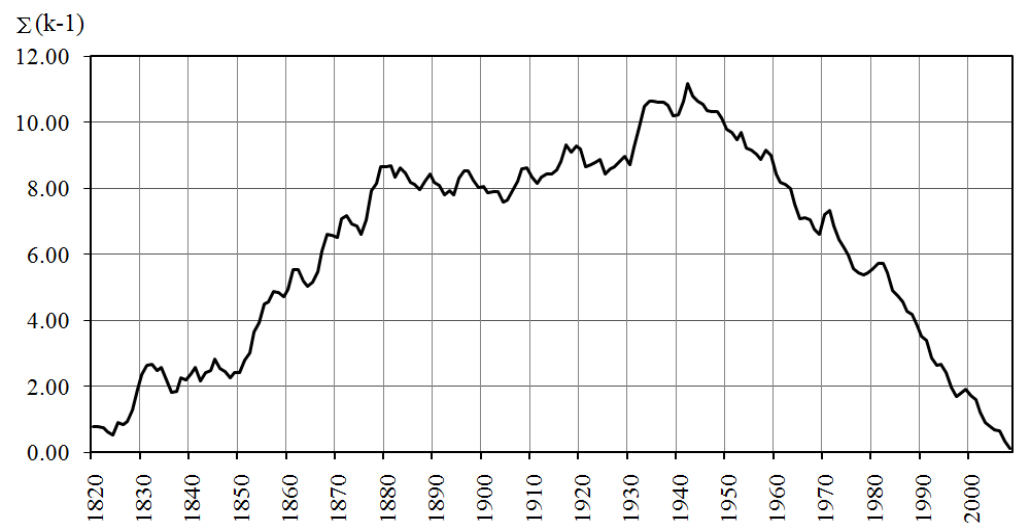

\section{Рис. 3. Різницева інтегральна крива модульних коефіцієнтів річкового стоку у гирловій ділянці Дніпра за період із 1820 по 2010 рp.}

Перша гребля каскаду (Запорізька ГЭС) була споруджена в 1934 р., зруйнована в 1941 р. і відновлена в 1947 р. Останнім водосховищем каскаду стало Канівське, заповнене в 1975-1976 рр. Створення каскаду водосховищ сприяло посиленню тенденції зниження стоку в пониззі Дніпра ${ }^{8,9}$.

На рис. 3 можна бачити різке зниження різницевої інтегральної кривої після 1942 р. Проведений аналіз водності Дніпра показав, що $\epsilon$ ряд періодів, які мають важливе значення у формуванні його сучасного екологічного стану. Нами виділено три основні періоди формування стоку Дніпра ${ }^{10,11}$ :

${ }^{8}$ Коржов С.I. Антропогенний вплив на екосистему пониззя Дніпра та можливі шляхи його послаблення. Наукові пращиі Украӥнського науково-дослідного гідрометеорологічного інституту. 2015. Вип. 267. С. 102-108.

9 Тімченко В.М., Карпова Г.О., Гуляева О.О., Коржов С.І. та ін. Прогноз впливу можливої реконструкції Каховської ГЕС на екосистеми пониззя Дніпра та Каховського водосховища. Наук. зап. Терноп. наи. пед. ун-ту., Сер. Біол. 2015. № 3-4 (64). С. 665-668.

${ }^{10}$ Овечко С.В., Коржов С.І., Гільман В.Л. Науково-практичні рекомендації щодо покращення екологічного стану слабопроточних водойм пониззя Дніпра. Херсон, $2015.28 \mathrm{c}$.

${ }_{11}$ Коржов Є.І. Науково-практичні рекомендації щодо покращення стану водних екосистем гирлової ділянки Дніпра шляхом регулювання їх зовнішнього водообміну. Херсон, 2018. 52 с. 
1) період до зарегулювання - 1818-1946 pр.;

2) період становлення стоку (формування каскаду водосховищ) 1947-1976 pp.;

3) період стабілізації стоку - з 1977 р. донині.

Середнє багаторічне значення стоку в пониззі Дніпра за період до зарегулювання складало $55,2 \mathrm{~km}^{3} /$ рік, в період становлення стоку $42,9 \mathrm{~km}^{3} /$ рік, і в період стабілізації стоку $-42,4 \mathrm{~km}^{3} /$ рік. Впродовж першого періоду зміна об'єму стоку складала в середньому 2-3\% від багатолітньої норми $\left(1,0-1,5 \mathrm{kм}^{3}\right)$. У період становлення (з 1947 по 1976 pp.), середнє багатолітнє значення стоку зменшилося на 12,3 км$^{3}$. Таке різке зниження водності зумовлене витратами великих об'ємів води на заповнення головних водосховищ каскаду та посиленням водоспоживання. Сумарне скорочення річного об'єму стоку порівняно 3 періодом до зарегулювання становить $16,2 \mathrm{kм}^{3}$, та нині тенденція до зменшення стоку тут продовжується. На рис. 4 наведена крива забезпеченості річних об'ємів стоку Дніпра в період стабілізації.

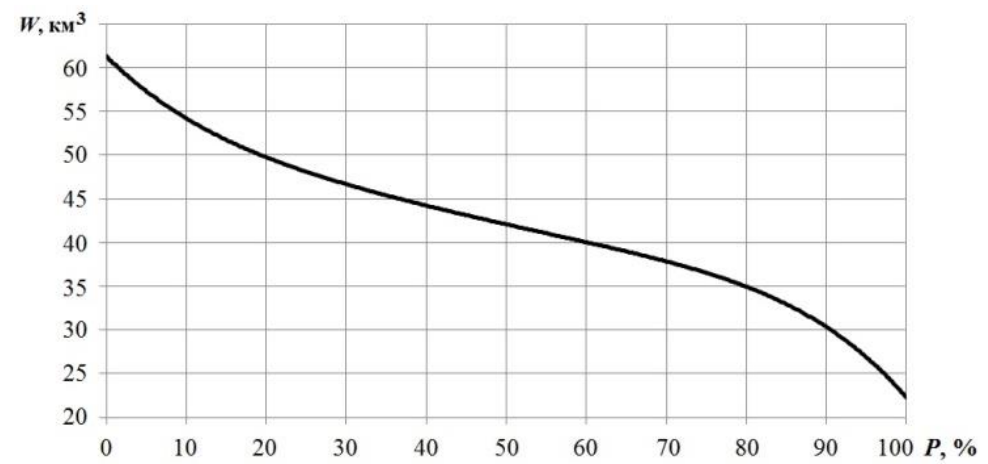

Рис. 4. Крива забезпеченості річних об'ємів стоку Дніпра У створі Каховської ГЕС за період 1977-2010 рp. $W_{\text {ср }}=42,4$ км $^{3}$,

$$
C_{V}=0,21, C_{S}=0,1
$$

Максимальні значення стоку за цей період не перевищували 59,1 км³/рік (1981р.). За період 2000-2017 pр. найбільший річний об'єм стоку був 57,6 км ${ }^{3}$ (2013р.), найменший - 19,4 (2015р.), середнє значення - 39 км $^{3}$.

Водність Південного Бугу наприкінці XX - початку XXI ст. також має тенденцію до зниження річних об'ємів стоку. За період 1914- 
1980 pp. річний об'єм стоку річки за даними водного посту смт Олександрівка становив $2,89 \mathrm{\kappa m}^{3}\left(91,5 \mathrm{~m}^{3} / \mathrm{c}\right)^{12}$.

У сучасний період від складає $2,58 \mathrm{~km}^{3}\left(81,9 \mathrm{~m}^{3} / \mathrm{c}\right)$. Згідно 3 даними середніх річних витрат води нами була побудована крива їх забезпеченості для Південного Бугу для водного посту смт Олександрівка (рис. 5).

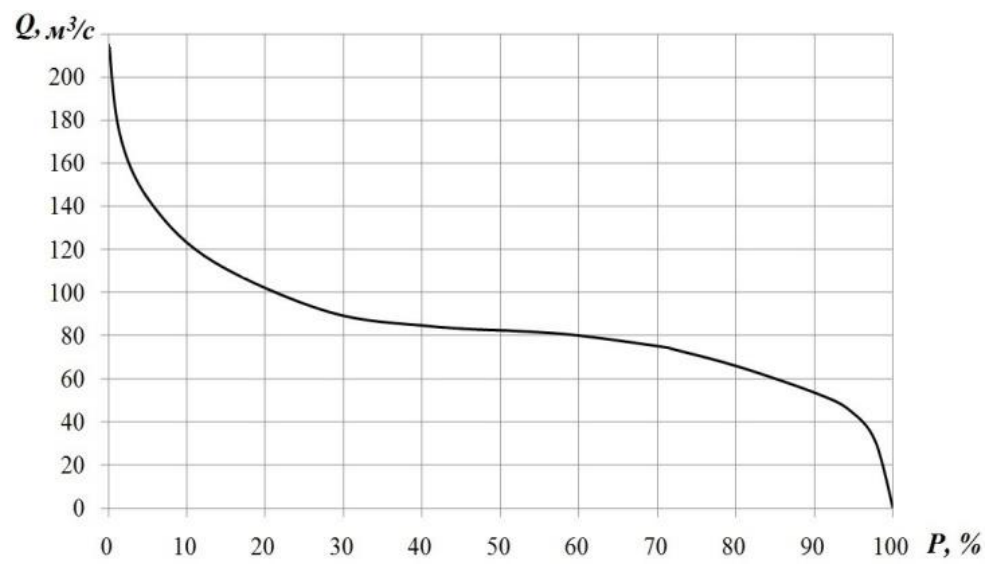

\section{Рис. 5. Крива забезпеченості витрат води Південного Бугу в районі смт. Олександрівка в сучасний період.$$
Q_{\mathrm{cp}}=81,9 \mathrm{~m}^{3} / \mathrm{c}, C_{V}=0,39, C_{S}=2 C_{V}^{13}
$$

Нині значні максимальні витрати маловірогідні, оскільки за даними спостережень останніх десятиліть по всій території України простежується тенденція до скорочення стоку річок і зменшення водного запасу в незначних за площею водних об'єктах, особливо у південних іiі регіонах ${ }^{14,15,16,17}$. Подібна зміна водності характерна також і для басейнів Дніпра та Південного Бугу.

12 Водне господарство в Україні / за ред. А.В. Яцика, В.М. Хорєва. Київ : Генеза, $2000.456 \mathrm{c}$.

${ }_{13}$ Korzhov Ye.I. Ecohydrological investigation of plain river section in the area of small hydroelectric power station influence. Collective monograph: Current state, challenges and prospects for research in natural sciences. Lviv - Toruń : Liha-Pres, 2019. 240 p. DOI: https://doi.org/10.36059/978-966-397-156-8/135-154.

Овечко С.В., Алексенко Т.Л., Коржов Є.І., Мінаєва Г.М. та ін. Гідроекосистеми Півдня України. Річка Каланчак. Херсон : Херсонська гідробіологічна станція НАН України, 2016. 100 с.

Коржов Є.I. Особливості гідрологічного режиму річки Каланчак. Наукові читання, присвячені Дню науки. Екологічні дослідження Дніпровсько-Бузького регіону. Херсон, 2016. Вип. 9. С. 12-19. 
Скорочення притоку прісних вод до Дніпровсько-Бузької гирлової області сприяє не лише зміні водно-балансових характеристик водних екосистем, а й значному переформуванню їх гідрохімічного режиму. Одним із найбільш чутливих та екологічно значущих елементів водного середовища $є$ солоність води, яка здебільшого $є$ лімітуючим фактором існування ряду гідробіонтів, якості їх життя й ареалу поширення.

\section{2. Кліматичні передумови підвищення солоності вод у водній екосистемі Дніпровсько-Бузької гирлової області}

Глобальні кліматичні зміни на сучасному етапі існування Дніпровсько-Бузької гирлової області не лише вплинули на скорочення притоку прісних вод до ії̈ водної системи, а й спричинили збільшення об’ємів надходження солоних вод через Кінбурнську протоку за рахунок поступового підвищення рівня моря. Нестача прісних вод у водному балансі Дніпровсько-Бузької гирлової області компенсується за рахунок наповнення водної екосистеми солоними водами шельфової зони Чорного моря.

За даними морських гідрометеостанцій України, розташованих уздовж берегів північно-західної частини Чорного моря і Криму (Приморське, Одеса, Хорли, Євпаторія, Севастополь, Херсонеський маяк, Ялта і Феодосія), поступове підвищення рівня Чорного моря фіксується дослідниками починаючи із середини минулого століття, причиною якого також вважають кліматичні зміни ${ }^{18,19}$.

Згідно із працею ${ }^{20}$ середній багатолітній рівень Чорного моря за період 1923-2005 pp., за даними станцій північного узбережжя, становить 477 см у ГВО колишнього СРСР. В окремих пунктах відхилення від середнього рівня моря становлять від +7 до -2 см. Вони

${ }^{16}$ Овечко С.В., Алексенко Т.Л., Коржов Є.І., Мінаєва Г.М. та ін. Екологічний стан урбанізованих заплавних водойм. Кардашинський лиман. Херсон : Херсонська гідробіологічна станція НАН України, 2015. 72 с.

${ }^{17}$ Korzhov Ye.I., Kucheriava A.M. Peculiarities of External Water Exchange Impact on Hydrochemical Regime of the Floodland Water Bodies of the Lower Dnieper Section. Hydrobiological Journal. Begell House (United States). 2018. Vol. 54. Issue 6. P. 104-113. DOI: 10.1615/HydrobJ.v54.i6.90.

18 Репетин Л.Н., Ильин Ю.П., Долотов В.В., Липченко М.М. Современные оценки атмосферных осадков, их вклада в водный баланс Черного моря. Экологическая безопасность прибрежной $u$ шельфовой зон $и$ комплексное использование ресурсов шельфа. 2009. Вып. 18. С. 193-204.

19 Ильин Ю.П., Репетин Л.Н. Климатические изменения гидрометеорологического режима северного и восточного побережий Чёрного моря. Экологическая безопасность прибрежной $u$ шельфовой зон $и$ комплексное использование ресурсов шельфа. 2012. Вып. 25. С. 157-169.

20 Ильин Ю.П., Репетин Л.Н., Белокопытов В.Н., Горячкин Ю.Н. та ін. Гидрометеоро-логические условия морей Украины. Т. 2: Черное море: МЧС и НАН Украины, Морское отделение Украинского научно-исследовательского гидрометеорологического института. Севастополь, 2012. 421 с. 
зумовлені як природними факторами (динамікою вод, характером згінно-нагінних явищ та ін.), так і особливостями методики вимірювань рівня. Різниця в середніх річних значень рівня за період 1875-2010 pp. склала 47 см. Найменший рівень води спостерігався в 1921 р. (450 см), а найбільший - у 2010 р. (497 см), що є історичним максимумом за весь період інструментальних досліджень.

На кривих зміни рівня для найбільш тривалих рядів спостережень виділяються кілька циклів у багаторічній мінливості (рис. 6).

Прийнято вважати, що з початку спостережень в Чорному морі до середини 20-х pp. ХХ ст. рівень води був відносно стабільним, із невеликою тенденцією до зниження, а з середини $20-\mathrm{X}$ pp. XX ст. чітко проявилося його підвищення ${ }^{21}$.

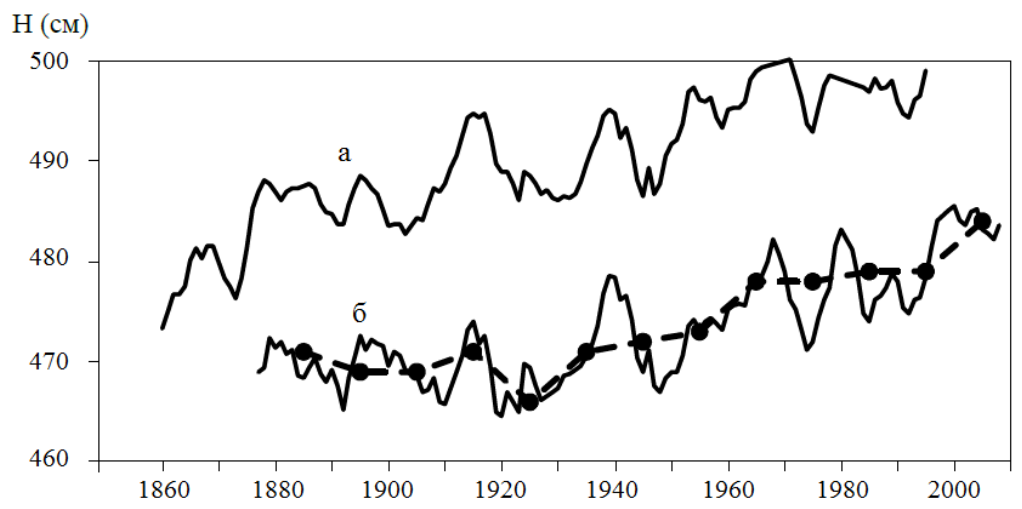

\section{Рис. 6. Багатолітні зміни рівня Чорного моря в Констанці (а) та Севастополі (б) - дані осереднені ковзною по 5 рокам. Пунктирна лінія - середні значення $3 а 10$ років $^{22}$}

Водночас найбільш тривалі ряди в Констанці та Сулині показують, що 31858 по 1875 р. рівень помітно підвищувався (див. рис. 6). Для періоду, який зазвичай співвідносять із періодом підвищення рівня Світового океану загалом, помітно три цикли: перший - майже безперервне зростання рівня (20-60 pp. XX ст.), другий - деяка його

${ }^{21}$ Гидрометеорология и гидрохимия морей СCCP. T. IV Черное море. Вып. 1. Гидрометеорологические условия. Санкт-Петербург : Гидрометеоиздат, 1991. C. 329-354.

Ильин Ю.П., Репетин Л.Н., Белокопытов В.Н., Горячкин Ю.Н. та ін. Гидрометеоро-логические условия морей Украины. Т. 2: Черное море: МЧС и НАН Украины, Морское отделение Украинского научно-исследовательского гидрометеорологического института. Севастополь, 2012. 421 с. 
стабілізація (70-90 pp. XX ст.), третій - розпочався в нульові роки XXI ст. і триває дотепер.

Остання за часом оцінка величини тренда, зроблена за даними 5 станцій кримського узбережжя для періоду 1947-2006 рр., вказала величину 2,3 мм/рік із дисперсією даних близько $14 \mathrm{~cm}^{23}$.

Згідно 3 даними праці ${ }^{24}$ залежність зміни рівня води у Чорному морі $(S L)$ з роками $(X)$ може апроксимуватися рівнянням: $S L=0,2143 X$. Основними причинами таких змін виділено збільшення кількості атмосферних опадів, що випадають над акваторією моря, зниження середніх річних швидкостей вітру й об'ємів випаровування ${ }^{25}$.

Основний параметр водної екосистеми Дніпровсько-Бузької гирлової області, на який вплинули зазначені вище зміни, - це солоність води. За даними досліджень 1963-1985 pp., наведеними у праці ${ }^{26}$, найбільша солоність вод відзначалася у західній частині Дніпровсько-Бузького лиману, яка знаходиться у безпосередньому гідравлічному зв'язку 3 акваторією Чорного моря. Середні річні значення солоності вод за хлорид-іоном на цій ділянці становили 3,00 4,98\%. Найбільші сезонні значення сягали 6,02-6,77\% у літньо-осінній період. Далі солоність вод зменшувалася у напрямку річкових систем. На центральній ділянці Дніпровсько-Бузького лиману її річні значення становили 1,94-2,75\%, у східній частині - 0,56-1,55\%. У гирлі Південного Бугу солоність переважну частину року коливалася в межах 2-3\%. Води гирлової ділянки Дніпра мали солоність нижчу за 1\%о (табл. 1).

23 Ильин Ю.П., Репетин Л.Н., Белокопытов В.Н., Горячкин Ю.Н. та ін. Гидрометеоро-логические условия морей Украины. Т. 2: Черное море: МЧС и НАН Украины, Морское отделение Украинского научно-исследовательского гидрометеорологического института. Севастополь, 2012. 421 с.

Ильин Ю.П. Регрессионные зависимости среднегодовых показателей гидрометеорологических условий Черноморского побережья Украины. Наукові праці Українського науково-дослідного гідрометеорологічного інституту. 2014. Вип. 266. С. 58-62.

Ильин Ю.П. Длиннопериодные колебания показателей гидрометеорологического режима Черноморского побережья Украины. Наукові праиі Українського науково-дослідного гідрометеорологічного інституту. 2015. Вип. 257. C. $88-95$.

26 Жукинский В.Н., Журавлева Л.А., Иванов А.И., Тимченко, В.М. и др. Днепровско-Бугская эстуарная экосистема. АН УССР. Ин-т гидробиологии. Київ : Наук. думка, 1989. 240 с. 
Середні річні значення солоності води (\%о)

у Дніпровсько-Бузькому лимані в різні періоди досліджень

\begin{tabular}{|c|c|c|}
\hline \multirow{2}{*}{ Ділянка лиману } & \multicolumn{2}{|c|}{ Періоди досліджень } \\
\cline { 2 - 3 } & $\mathbf{1 9 6 3 - 1 9 8 5}$ pp. $^{2}$ & $\mathbf{2 0 1 3 - 2 0 1 8}$ pp.* $^{*}$ \\
\hline Західна & $3,00-4,98$ & $6,5-7,2$ \\
\hline Центральна & $1,94-2,75$ & $4,0-5,0$ \\
\hline Східна & $0,56-1,55$ & $1,9-3,3$ \\
\hline
\end{tabular}

Примітка: *усереднені на основі даних авторських щуосезонних експедииійних виїздів до Дніпровсько-Бузького лиману (весна, літо, осінь 2013-2018 рр.)

Найбільші значення підвищення солоності відзначаються у Дніпровсько-Бузькому лимані. У західній частині лиману солоність збільшилась на 2,7-3,5\% i нині переважно становить 6,5-7,2\%, у центральній частині лиману - на 2,1-2,3\%. Найменші значення підвищення солоності води в лимані зафіксовані у східній частині - на $1,3-1,8 \%$.

У 80 -х рр. минулого століття збільшення значень солоності води у поверхневому та придонному шарах руслової мережі Дніпра та східній частині Дніпровсько-Бузького лиману майже завжди відбувалося при інтенсивних явищах вітрового нагону солоних вод у дніпровську дельту та в періоди екстремально-низької водності річки, які з появою каскаду водосховищ у ії̈ нижній течії майже зникли.

За сучасними даними експедиційних досліджень у червні 2018 р. до Дніпровсько-Бузького лиману та гирлової ділянки Дніпра нами було зафіксовано явище нагону води помірної інтенсивності, яке тривало тут iз 21 по 24 червня 2018 p.

Швидкість приземного вітру в цей період становила 4-6 м/с, із поривами до 12-14 м/с. На рис. 7 наведено хід рівня води за період нагону.

Середньодобові рівні води під час проходження нагінного явища становили 0,18-0,28 м БС при нормальних їх значеннях у цей період року (до та після нагону води) $-0,02-0,08$ м БС.

Напередодні нагону води (21 червня) в русловій мережі відзначалася пряма температурна стратифікація у поверхневому шарі. Солоність вод у русловій мережі в районі м. Херсона становила $0,25-0,28 \%$.

Нагін води тривав із ранку 22 до вечора 23 червня. У перший день нагінного явища, поблизу морського краю дельти, концентрація кисню у придонних шарах знизилася до 4,2-4,6 мг/дм³. Такий перерозподіл величин вірогідно був спричинений проникненням більш прохолодних

27 Жукинский В.Н., Журавлева Л.А., Иванов А.И., Тимченко, В.М. и др. Днепровско-Бугская эстуарная экосистема. АН УССР. ИН-т гидробиологии. Киев : Наук. думка, 1989. 240 с. 
і солоних вод до руслової мережі гирлової ділянки Дніпра. Солоність вод у придонному шарі становила 5,0-5,3\%о при фонових значеннях тут менше $0,3 \%$ (рукав Рвач у районі с. Кізомис). Температурна стратифікація стала більш вираженою і поширилася до придонних шарів.

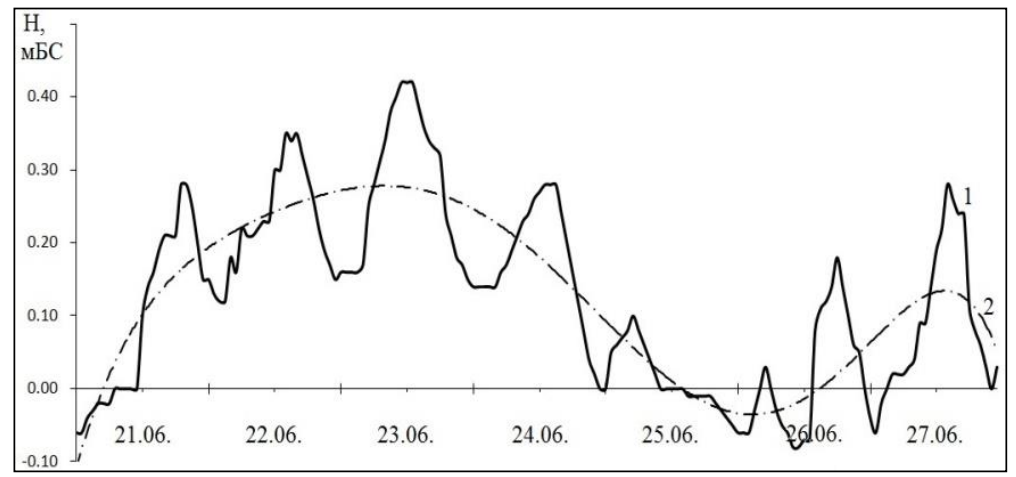

\section{Рис. 7. Внутрішньодобовий хід (1) і динаміка середньодобових значень рівня води (2) в русловій мережі Дніпра в районі м. Херсона згідно 3 натурною зйомкою 21-27 червня 2018 p. $^{28}$}

Вище за течією (10 км від морського краю дельти) в районі протоки Забіч також відзначалися подібні процеси. У придонних шарах вміст кисню становив 4,5-5,0 мг/дм ${ }^{3}$, солоність вод $-4,5-5,0 \%{ }^{29}$.

Така різка зміна вмісту розчиненого у воді кисню та температурних показників середовища може негативно відобразитися на існуючих у русловій мережі гідробіонтах, особливо на представниках придонної флори та фауни. Якщо в нормальних умовах дефіцит кисню у воді не відзначається (середні значення насиченості 86-90\%), то при нагінному явищі та збільшенні солоності, спричиненими проникненням солоних вод до руслової мережі, нами зафіксовано зменшення насиченості киснем до 40-46\%, тобто у $2-2,5$ рази. Значення концентрації розчиненого кисню у воді впродовж 22-23 червня 2018 p. у придонному шарі також знизилися більш ніж вдвічі, причому найнижча концентрація відзначалася в русловій мережі біля морського

${ }^{28}$ Коржов С.І., Жежеря В.А., Дубняк С.С. До питання змін кисневого режиму водних мас руслової мережі пониззя Дніпра під час згінно-нагінних явищ. Наукові читання, присвячені Дню науки. Екологічні дослідження Дніпровсько-Бузького регіону. Херсон, 2018. Вип. 11. С. 7-12.

29 Коржов Є.І., Жежеря В.А., Дубняк С.С. До питання змін кисневого режиму водних мас руслової мережі пониззя Дніпра під час згінно-нагінних явищ. Наукові читання, присвячені Дню науки. Екологічні дослідження Дніпровсько-Бузького регіону. Херсон, 2018. Вип. 11. С. 7-12. 
краю дельти (у місці найбільшої солоності води) та незначно збільшувалася вверх за течією.

У Дніпровсько-Бузькому лимані в цей час солоність води у поверхневому шарі центральної частини становила біля 12,0\%о при нормальних значеннях у нинішній період 4,0-5,0\%о. У східній частині лиману в межах судового каналу солоність сягала значень 6,8-8,0\%о при сучасній нормі 1,9-3,3\%.

Після проходження явища (24 та 25 червня) досліджені показники знову встановилися на рівні фонових значень. Їх розподіл за глибиною через значне вертикальне перемішування вод під час нагону води та різкого відходження нагінної хвилі став більш однорідним, ніж до нагону. Відтік нагінних вод також добре фіксувався й за показниками солоності, вони повернулися до фонових значень $(0,25-0,26 \%)$ та вирівнялися за глибиною ${ }^{30}$.

Дослідження цього явища нагону на гирловій ділянці Дніпра вказує на те, що такі ситуації не лише сприяють проникненню значно солоних вод із Дніпровсько-Бузького лиману до руслової мережі, але й здатні спричиняти значний короткостроковий перерозподіл ряду гідрохімічних і гідрофізичних показників водних мас, що є найбільш вираженим у придонних шарах і можуть мати вкрай негативний вплив на екосистему регіону.

Дані натурних досліджень, аналіз їх просторово-часового розподілу підтверджує, що поступове підвищення солоності води у ДніпровськоБузькій гирловій області пов'язане з активним надходженням солоних i скороченням прісних вод. Явища нагону вод у гирлові ділянки Дніпра та Південного Бугу здатні суттєво підвищувати солоність води у їх водній системі, хоча й на відносно короткий строк.

Наведені нами тенденції до зміни режиму солоності у водній екосистемі Дніпровсько-Бузької гирлової області мають велике значення у формуванні якості водного середовища регіону досліджень. Підвищення солоності води може спричинити зникнення ендемічних, рідкісних видів гідробіонтів, докорінно змінити видовий склад флори та фауни регіону, збільшити кількість інвазивних видів, нетипових для території Півдня України, порушити усталені потоки енергї в екосистемах локального рівня, зробити гирлову ділянку Дніпра не придатною для водопостачання та водоспоживання тощо.

\section{ВИСНОВКИ}

1. Сукупна дія факторів природного й антропогенного впливу на Дніпровсько-Бузьку гирлову область спричинили на сучасному етапі

${ }^{30}$ Коржов Є.І., Жежеря В.А., Дубняк С.С. До питання змін кисневого режиму водних мас руслової мережі пониззя Дніпра під час згінно-нагінних явищ. Наукові читання, присвячені Дню науки. Екологічні дослідження Дніпровсько-Бузького регіону. Херсон, 2018. Вип. 11. С. 7-12. 
переформування ряду гідрологічних параметрів водної екосистеми, що спричинило зміну у режимі солоності вод об'єкта досліджень.

2. Скорочення об'єму прісноводного стоку Дніпра як основного джерела прісних вод системи у 2000-х рр. порівняно 3 періодом до становлення каскаду водосховищ на ньому за рахунок дії кліматичних та антропогенних факторів сягає значення 16,2 км³. Об'єм стоку Південного Бугу в 2000-х pp. порівняно 3 початком минулого століття зменшився на $0,31 \mathrm{\kappa m}^{3}$.

3. Нестача прісних вод у водному балансі Дніпровсько-Бузької гирлової області компенсується за рахунок наповнення водної екосистеми солоними водами шельфової зони Чорного моря. Збільшення об'ємів надходження солоних вод через Кінбурнську протоку на сучасному етапі спричинено сполученою зміною кліматичних факторів, які сприяють поступовому збільшенню рівня води Чорного моря.

4. За даними регулярних експедиційних досліджень 2013-2018рp., найбільші значення підвищення солоності відзначаються у Дніпровсько-Бузькому лимані. У західній частині лиману солоність збільшилася на 2,7-3,5\% i нині переважно становить 6,5-7,2\%, в центральній частині лиману - на 2,1-2,3\%о та складає 4,0-5,0\%. Найменші значення підвищення солоності води в лимані зафіксовані у східній частині - на 1,3-1,8\%, і нині солоність тут становить $1,9-3,3 \%$.

5. Збільшення солоності вод у водній екосистемі ДніпровськоБузької гирлової області мають велике значення у формуванні якості водного середовища регіону досліджень. Продовження процесу осолонення може спричинити зникнення ендемічних, рідкісних видів гідробіонтів, докорінно змінити видовий склад унікальної флори та фауни регіону, зробити гирлову ділянку Дніпра не придатною для водопостачання та водоспоживання, що може визвати не лише значні екологічні проблеми в регіоні, а й суттєві соціально-економічні наслідки.

\section{АНОТАЦІЯ}

У праці розглянуто основні фактори формування солоності вод Дніпровсько-Бузької гирлової області та ї просторово-часову мінливість, спричинену глобальними кліматичними змінами. Встановлено, що сукупна дія факторів природного й антропогенного впливу на Дніпровсько-Бузьку гирлову область зумовила на сучасному етапі переформування ряду гідрологічних параметрів водної екосистеми, що спричинило зміну в режимі солоності вод об'єкту досліджень.

Скорочення об'єму прісноводного стоку Дніпра та Південного Бугу порівняно $з$ періодом до становлення каскаду водосховищ на ньому за рахунок дії кліматичних та антропогенних факторів нині перевищило 
$16,5 \mathrm{\kappa м}^{3}$. Нестача прісних вод у водному балансі Дніпровсько-Бузької гирлової області компенсується за рахунок наповнення водної екосистеми солоними водами шельфової зони Чорного моря. Найбільш інтенсивне збільшення значень солоності води нами виявлене у Дніпровсько-Бузькому лимані, зокрема у його західній частині (на 2,7-3,5\%o), і нині переважно становить 6,5-7,2\%. Матеріал узагальнює дані авторських щосезонних експедиційних виїздів до ДніпровськоБузької гирлової області в теплий період 2013-2018 рр. та має на меті звернути увагу дослідників на переформування режиму солоності води, які відбуваються тут у сучасний період під впливом кліматичних змін, і можливі екологічні та соціально-економічні наслідки зазначених змін.

\section{ЛІТЕРАТУРА}

1. Водне господарство в Україні / за ред. А.В. Яцика, В.М. Хорєва. Київ : Генеза, 2000. 456 с.

2. Гидрометеорология и гидрохимия морей CCCP. T. IV Черное море. Вып. 1. Гидрометеорологические условия. Санкт-Петербург : Гидрометеоиздат, 1991. С. 329-354.

3. Жукинский В.Н., Журавлева Л.А., Иванов А.И., Тимченко В.М. и др. Днепровско-Бугская эстуарная экосистема. АН УССР. Ин-т гидробиологии. Київ : Наук. думка, 1989. 240 с.

4. Ильин Ю.П. Длиннопериодные колебания показателей гидрометеоро-логического режима Черноморского побережья Украины. Наукові праці Украӥнського науково-дослідного гідрометеорологічного інституту. 2015. Вип. 257. С. 88-95.

5. Ильин Ю.П., Репетин Л.Н. Климатические изменения гидрометеоро-логического режима северного и восточного побережий Чёрного моря. Экологическая безопасность прибрежной и шельфовой зон и комплексное использование ресурсов шельфа. 2012. Вып. 25. C. $157-169$.

6. Ильин Ю.П. Регрессионные зависимости среднегодовых показателей гидрометеорологических условий Черноморского побережья Украины. Наукові прачі Українського науково-дослідного гідрометеорологічного інституту. 2014. Вип. 266. С. 58-62.

7. Ильин Ю.П., Репетин Л.Н., Белокопытов В.Н., Горячкин Ю.Н. та ін. Гидрометеорологические условия морей Украины. Т. 2: Черное море: МЧС и НАН Украины, Морское отделение Украинского научноисследовательского гидрометеорологического института. Севастополь, 2012. $421 \mathrm{c}$.

8. Коржов Є.I. Антропогенний вплив на екосистему пониззя Дніпра та можливі шляхи його послаблення. Наукові праці Украӥнського науково-дослідного гідрометеорологічного інституту. 2015. Вип. 267. C. $102-108$. 
9. Коржов Є.I., Бородін А.В. Гідрографічна характеристика Дніпровсько-Бузького лиману в межах НПП «Нижньодніпровського». Наукові читання, присвячені Дню науки. Екологічні дослідження Дніпровсько-Бузького регіону. Херсон, 2018. Вип. 11. С. 56-59.

10. Коржов C.I., Жежеря В.А., Дубняк C.C. До питання змін кисневого режиму водних мас руслової мережі пониззя Дніпра під час згінно-нагінних явищ. Наукові читання, присвячені Дню науки. Екологічні дослідження Дніпровсько-Бузького регіону. Херсон, 2018. Вип. 11. С. 7-12.

11. Коржов Є.I. Науково-практичні рекомендації щодо покращення стану водних екосистем гирлової ділянки Дніпра шляхом регулювання їх зовнішнього водообміну. Херсон, 2018. 52 c.

12. Коржов С.І. Особливості гідрологічного режиму річки Каланчак. Наукові читання, присвячені Дню науки. Екологічні дослідження Дніпровсько-Бузького регіону. Херсон, 2016. Вип. 9. С. 12-19.

13. Коржов Е.И. Некоторые экологически значимые аспекты водного режима Нижнего Днепра. Наукові читання присвячені Дню науки. Херсон, 2010. Вип. 3. С. 4-9.

14. Коржов Е.И. Современная гидрографическая характеристика низовья Днепра. Наукові читання присвячені Дню науки. Херсон, 2011. Вип. 4. С. 4-17.

15. Овечко С.В., Алексенко Т.Л., Коржов С.І., Мінаєва Г.М. та ін. Гідроекосистеми Півдня України. Річка Каланчак. Херсон : Херсонська гідробіологічна станція НАН України, 2016. 100 с.

16. Овечко С.В., Алексенко Т.Л., Коржов С.І., Мінаєва Г.М. та ін. Екологічний стан урбанізованих заплавних водойм. Кардашинський лиман. Херсон : Херсонська гідробіологічна станція НАН України, $2015.72 \mathrm{c}$.

17. Овечко С.В., Коржов Є.І., Гільман В.Л. Науково-практичні рекомендації щодо покращення екологічного стану слабопроточних водойм пониззя Дніпра. Херсон, 2015. 28 с.

18. Репетин Л.Н., Ильин Ю.П., Долотов В.В., Липченко М.М. Современные оценки атмосферных осадков, их вклада в водный баланс Черного моря. Экологическая безопасность прибрежной и шельфовой зон и комплексное использование ресурсов шельфа. 2009. Вып. 18. C. 193-204.

19. Тімченко В.М., Карпова Г.О., Гуляева О.О., Коржов С.І. та ін. Прогноз впливу можливої реконструкції Каховської ГЕС на екосистеми пониззя Дніпра та Каховського водосховища. Наукові записки Тернопільського начіонального педагогічного університету. Серія Біологія. 2015. № 3-4 (64). 2015. С. 665-668.

20. Швец Г.И. Многовековая изменчивость стока Днепра. Москва : Гидрометеоиздат, 1979. 84 с. 
21. Korzhov Ye.I. Ecohydrological investigation of plain river section in the area of small hydroelectric power station influence. Collective monograph: Current state, challenges and prospects for research in natural sciences. Lviv - Toruń : Liha-Pres, 2019. 240 p. DOI: https://doi.org/10.36059/978-966-397-156-8/135-154.

22. Korzhov Ye.I., Kucheriava A.M. Peculiarities of External Water Exchange Impact on Hydrochemical Regime of the Floodland Water Bodies of the Lower Dnieper Section. Hydrobiological Journal. Begell House (United States). 2018. Vol. 54. Issue 6. P. 104-113. DOI: 10.1615/HydrobJ.v54.i6.90.

23. Timchenko V.M., Korzhov Y.I., Guliayeva O.A., Batog S.V. Dynamics of Environmentally Significant Elements of Hydrological Regime of the Lower Dnieper Section. Hydrobiological Journal. Begell House (United States). 2015. Vol. 51. Issue 6. P. 75-83. DOI: 10.1615/HydrobJ.v51.i6.90.

\section{Information about authors:}

Korzhov Ye. I.,

Candidate of Geographic Sciences,

Senior Lecturer at the Department of Water Biological Resources and Aquaculture

Kherson State Agrarian University 23, Stritenskaya str., Kherson, 73006, Ukraine

Honcharova O. V.,

Candidate of Agricultural Sciences, Associate Professor at the Department of Water Biological Resources and Aquaculture

Kherson State Agrarian University

23, Stritenskaya str., Kherson, 73006, Ukraine 